\title{
Heroines of Polish Cinema
}

\author{
By Ewa Mazierska
}

Spring 2002 Issue of KINEMA

\section{AGNIESZKA AND OTHER SOLIDARITY HEROINES OF POLISH CINEMA}

Agnieszka is the heroine of two of Andrzej Wajda's films, Cztowiek z marmuru (Man of Marble, 1976) and Człowiek z żelaza (Man of Iron, 1981). However, in Man of Iron, Agnieszka has quite a different personality and has a different narrative function, compared with Agnieszka in Man of Marble. What concerns me in this article, is the nature and socio-political background of Agnieszka's creation and her transformation from heroine of Man of Marble to Man of Iron and subsequently her 'post-Wajda incarnations' in later Polish films about the Solidarity movement.

\section{"Iron Agnieszka"}

In Man of Marble, which is set in the mid-1970s, Agnieszka is a final year film college student. She is completing her diploma film, financed by the state television, which also provides her with crew and equipment. Agnieszka decides to make a documentary, entitled Gwiazdy jednego sezonu (Falling Stars) about a bricklayer, named Mateusz Birkut, who took part in building the city and the steelworks of Nowa Huta, which was regarded as the greatest enterprise of the first decade of post-war Poland. Birkut enjoyed a short career in the 1950s as a champion of socialist work of the 1950s, known as 'stakhanovchik', when he served as an example to be followed by ordinary workers and was even immortalised in marble socialist realistic sculptures. After that he virtually disappeared without trace from Polish politics and social life. The mystery of his downfall is the main reason for Agnieszka's decision to make a film based on his life. There are, however, deeper motives for her interest in the forgotten socialist celebrity. At one point Agnieszka claims: 'this is the history of my parents' which suggests that she tries to discover her own roots through the story of Birkut. Maria Kornatowska suggests that her feverish activity and idealism results from belonging to the generation born in the 1950s, who struggle to find a place in the world and to have a distinctive identity. ${ }^{(1)}$ Instead, they must find something to fill their inner void, to help them deal with their lack of history. I will also suggest that Agnieszka shares with the twenty-something generation of the 1970s a certain individualism and urge to be successful, to make a career, which was lacking amongst earlier generations, particularly women. These values can be associated with the political and social climate of the 1970s, when Edward Gierek was a leader of the Polish Communist Party (Polska Zjednoczona Partia Robotnicza), described as times of 'real socialism', characterised by openness to the West, consumerism and a relative neglect of ideology.

In the history of Polish cinema the 1970s are characterised primarily by the Cinema of Moral Concern, regarded as the most distinctive paradigm in Polish cinematography, alongside the Polish School. The Cinema of Moral Concern was created by directors such as Krzysztof Kieślowski, Krzysztof Zanussi, Feliks Falk, Agnieszka Holland, Janusz Kijowski, Barbara Sass and Andrzej Wajda himself, who was the oldest member of this group. Thematically, their films concentrated on the pathologies of 'real socialism': widespread bureaucracy and corruption, materialism and greed, nepotism and ruthlessness in achieving career goals, as well as people's double moral standards: one for home, one for work. The films often articulated the frustration of the younger generation, whose ambitions were thwarted by their seniors, who had money and power. It can also be argued that in comparison with the films, made in previous decades, the Cinema of Moral Concern gave more prominent roles to women.

Stylistically, the filmmakers, belonging to this paradigm, many of whom had a considerable experience in documentary, draw on realist-documentary tradition. At the same time, there was a strong element of selfreflexivity in their films -- many of the characters represented professions such as journalists, filmmakers, actors, and the films concentrated on their professional activities, rather than on their private lives. The main reason for that was to question the role of the filmmaker/artist in the world where moral values, such as honesty, selflessness and truth became marginalised and even forgotten. By choosing a filmmaker as a main character and utilising realist-documentary tradition, Wajda made a film which firmly belongs to the Cinema of Moral Concern. Due to its emphasis on the Polish 1950s, Man of Marble can be also regarded as a bridge between the Cinema of Moral Concern and the earlier cinematic schools, such as socialist realism and the Polish School. 
The very process of filmmaking reveals that Agnieszka has both the interest and suitable temperament for investigative journalism; she appears to have no initial political or ideological agenda, but is driven by curiosity about the fate of her character, as well as a desire to make an interesting, successful film. In line with her method of working, which involves tracing people who met Birkut at various times in his life, Wajda's film takes the shape of an 'investigative film', resembling the structure of Citizen Kane (1941) by Orson Welles, The Third Man (1949) by Carol Reed, as well as one of the main films of the Cinema of Moral Concern, Amator (Camera Buff, 1979) by Krzysztof Kieślowski. It is narrated partly by flashbacks, presenting Birkut at various stages of his life, partly by interviews, which Agnieszka conducts with people who knew him in person, including his old colleagues and a filmmaker, whose films established Birkut as a national symbol, a 'man of marble'. Finding these people and persuading them to talk about Birkut proves very difficult, as they have changed very much in the meantime and often regard the 1950s as a painful or shameful period of their lives. In order to succeed Agnieszka has to be cunning, lying, when necessary, even abusing interviewees' trust. Many people submit to her charisma, others give in to avoid being continuously harassed by her. In this respect she is very different from those whom she interviews and who are shown in the flashbacks -- all of them, including Birkut, sooner or later failed, either by being imprisoned, forced to renounce their privileged positions in society or by being forced to compromise their high ideals.

This unusual strength of character also makes Agnieszka a rarity amongst Wajda's characters, who are often (particularly in the 'Polish School' period) heroic, but at the same time doomed to failure. According to the Romantic tradition they fight not so much to win, as to prove their love and loyalty to their country. ${ }^{(2)}$ Wajda's heroine, on the other hand, does not carry the heavy 'baggage of Romanticism'. I will even suggest that in Man of Marble she is not particularly patriotic. Moreover, she wants her film to resemble an American movie, not a 'Polish school' classic. Agnieszka's professional credentials are demonstrated not only by her attitude, but also by her technical skill. Her handheld camera, used for filming marble statues, arouses the admiration of Mr. Leonard, her cameraman, and her ability to find footage, hidden deep in the television archive, secures the respect of her editor. Their high opinion of Agnieszka is particularly significant, as the cameraman and the editor are both very experienced.

Another of Agnieszka's important characteristics is her authority over men. Firstly, she is a female director with an all male-crew, which includes Mr. Leonard and two young assistants. Although Mr. Leonard calls her 'my daughter', it is Agnieszka who assumes the role of parent and mentor, persuading him to shoot according to her style. The assistants are treated like dogsbodies, moved around when it suits her, ordered to perform the mundane and thankless tasks of hiding cameras and deflecting the attention of people who might obstruct her plans. One scene, which demonstrates most poignantly her dominant position over her male crew is shot in the television archive where Agnieszka watches documentary footage of Birkut. When her two co-workers sit near the screen, obscuring her view, she asks them to move behind her, and they obey her instantly, virtually disappearing into the darkness, as if completely insignificant. Agnieszka is also commanding in her relationship with the television producer, who provides her with crew and equipment, and thanks to whom she can make her film. He is very cautious not to touch on subjects which might upset the authorities and therefore does not like Agnieszka's idea of re-discovering the Stalinist past. Instead, he encourages her to make films, which will highlight socialist achievements, most notably Huta Katowice (Katowice Steelworks), the largest Polish state investment of the 1970s. She, on the other hand, constantly challenges him, accusing him of opportunism and cowardice, especially shameful in the light of his young age of 28 years. They are always shown walking together along the corridors of the television building. The producer walks quickly, as if trying to run away from her, but is unsuccessful -- she has no difficulty keeping up with him. On another occasion we see him hiding in the men's toilet when he glimpses Agnieszka walking down the corridor towards him. (In fact, this scene features in Man of Iron, but is included in the flashbacks, referring to the same period as Man of Marble).

Another man, whom Agnieszka manages to dominate, although in a different sense, is Mateusz Birkut himself, the titular 'fallen star' of her own film. Firstly, in contrast to the scenario, which Laura Mulvey applies to the classic Hollywood period, according to which woman is the image and man -- the bearer of the look ${ }^{(3)}$, in Wajda's film it is Agnieszka, who bears the look, while Birkut is only an image. Moreover, by using footage, which was hidden for many years in film archives and by discovering his marble statues in the cellar of the National Museum and by filming them, as well as by talking about him with his old friends, 
she re-creates Mateusz Birkut, transforming him into a man whom nobody knew and would not know if she had not embarked on her project. Her almost god-like power of resurrecting Birkut is made even more apparent when we learn that at the time Agnieszka made 'Falling Stars', Birkut had already been dead for several years. Tadeusz Sobolewski compares her to a knight from a fairy tale who revive people changed into stones. ${ }^{(4)}$

The documentary footage, which Agnieszka views in the television archive, reveals many episodes showing their protagonists in a bad light, either by revealing their past acts of political opportunism and malice, or by demonstrating that over the years they lost their honesty and idealism. This is the case of Burski, the director, who discovered and 'created' Birkut in the 1950s. Agnieszka discovers that Burski first wanted to make an 'honest' film about Nowa Huta, showing the extremely difficult conditions, in which the workers, recruited from all over the country, lived and worked. Soon afterwards Burski made They Built Our Happiness, glorifying the workers' conditions and praising their bricklaying skills. Agnieszka learns that this was not done by the technique of cinema verite, but by carefully arranging events which were subsequently filmed. In the 1970s Burski is celebrated as the most acclaimed Polish director. Agnieszka meets him after his return from an international festival, where he sat on the jury.

There is a parallel between the careers of Burski and Andrzej Wajda. The success of both of them was at least partially a consequence of their ability to adjust to political circumstances, giving up their desire to depict truth, when it could jeopardise their professional prospects. The connection between Wajda and Burski is reinforced by including Andrzej Wajda's name in the credits of Burski's They Built Our Happiness as his assistant. Discovering Burski's dubious route to success, Agnieszka in a sense calls into question the moral credentials of the most celebrated Polish director. It is worth adding that hardly any real Polish filmmaker, film critic or investigative journalist ever had the courage or will to question Wajda's moral credentials. This in itself elevates Agnieszka to the status of a 'super-journalist'. Moreover, by showing that she can not be silenced by any authority Wajda further emphasizes her moral superiority over artists from the earlier generation, like Burski and himself. Accordingly, critics drew parallels between Wajda's Agnieszka and one of the most distinguished directors of the Cinema of Moral Concern -- Agnieszka Holland. ${ }^{(5)}$

Amongst those, who feature in the 1950s documentaries, which Agnieszka examined, is Wincenty Witek, Birkut's friend and fellow bricklayer, who was probably responsible for handing him a red hot brick, after which he was unable to fulfil his role as a champion of socialist work. Like Burski, Witek changed greatly over the years. First we see him as a decent man, who opposes stakhanovite methods on the grounds that they will lead to increasing worker's daily workload and consequently, greater exploitation. This even leads to his persecution by the 'security office' (Polish equivalent of the KGB). Later, however, he becomes involved in official politics, encouraging ordinary people to vote for the communist party. The peak of Witek's career is when he becomes the Director General of Huta Katowice. Agnieszka interviews him at this point and notices that he is now using the same rhetoric which was used by party officials who fought against him twenty years earlier. This insight gives her an authority over him -- she does not seem at all impressed by his current high position or the vision of the great expanse of steelworks, which Witek shows her from a helicopter. To her, he is only a vehicle in her discovery of Birkut's past and one has the impression that she does not even take Witek seriously. Her superiority over Witek is also conveyed visually. She is the taller and interviewing him on uneven ground, stands above him, which gives the impression of her talking to someone diminutive, almost a gnome. The knowledge that he is the director of Huta Katowice, adds to the impression of Agnieszka's power.

Agnieszka is constantly on the move, travelling from Warsaw to the most distant parts of Poland, such as Nowa Huta, Katowice and Zakopane in the South and Gdańsk in the North. Sometimes she sleeps in the television studio or in a van; she does not mind where she will spend the next night. All her belongings are in a large, sack-like bag, which she carries slung over her shoulder. The bag symbolises her freedom and contempt for material possessions. In comparison with her, everyone she meets, the majority of whom are middle-aged men, are static. They seem to have very little control over their lives, being imprisoned in their jobs, homes and family responsibilities. All of them achieved much in terms of material success, having vast villas and houses with gardens, but feel emotionally dead. There is even a kind of sadness about them, probably resulting from their realisation of having betrayed the ideals and people of their youth. 
Her physical appearance connotes Agnieszka's contempt for middle class and feminine values. She always wears the same denim uniform, consisting of bootleg trousers and a long jacket, platform shoes, a long shawl and a large, man's umbrella. She wears no make-up and her fair hair is conveniently put in a bun. Her father, concerned about her marriage prospects, even gives her some money to buy 'better clothes', claiming that in her jeans no decent man will find her attractive. Although she accepts the gift with gratitude, it is obvious that she is not bothered about losing her chance of marriage. In spite of her apparent indifference towards her looks, she is very attractive and her simple clothes accentuate, rather than hide the fact. Men around her recognise her charm which she uses to achieve her professional objectives. For example, when she gets into Burski's car, straight after his return from a foreign trip, he initially wants to get rid of her, but after noticing her long legs and charming smile, lets her stay and drives her to his home.

The kind of femininity and sexuality that Agnieszka epitomised was new to the Polish cinema. It was more reminiscent of (or even influenced by) the way young women looked and behaved in the West, than of the traditional standards of Polish femininity. Agnieszka, in my opinion, could be compared to the roles of independent women, which Jane Fonda or Sally Field created in the 1960s and 1970s. The novelty of Agnieszka's femininity led Polish critics, even those, who discussed her from a feminist perspective, to treat her not really as a woman, but as a 'man in disguise'. For example, Maria Kornatowska and Maciej Koziol describe Agnieszka as 'masculine' and 'bisexual' and Wiktor Woroszylski describes her as 'female Don Quixote.'(6) Similarly, Dorota Roszkowska claims that 'Agnieszka has very few specifically female features', that she is more masculine than feminine or 'sexually ambivalent'. Roszkowska also recognizes that Wajda's character encapsulates the changes which took place at the time the film was made, particularly women's emancipation and their invasion of traditionally male territories. ${ }^{(7)}$ I strongly disagree with the opinion that Agnieszka is masculine or 'bisexual'. As I previously mentioned, in spite of her wearing trousers and no make-up, she is attractive and feminine. The views, which I referred to, in my opinion tell us not only what kind of person Agnieszka is, but also about how strongly Polish culture is influenced by a particular image of femininity -- that of 'Polish Mother', which I will analyse in due course. Even Kornatowska and Roszkowska seem to regard it as a standard, against which all other models of femininity should be judged.

The last scene in Man of Marble shows Agnieszka walking the long corridor of the television studio with Birkut's son, Maciek Tomczyk, as she used to walk with the producer. Although it is Agnieszka, who brought him to Warsaw and introduced him to television, he is walking ahead, as if leading her. At times he walks slower, in order to put his hand on her back, in a gesture of support and perhaps tenderness. This is the only scene in the film, when Agnieszka is shown being led and supported by a man. She welcomes the gesture, which reveals her vulnerability and femininity. I find this episode particularly important, as in it Wajda (perhaps unconsciously) prepares us for an encounter with another incarnation of Agnieszka -- the one, who will be the heroine of Man of Iron.

\section{Agnieszka as Polish Mother}

In Man of Iron the part of Agnieszka is smaller and less central to the narrative than in Man of Marble. In contrast to the first part of Wajda's diptych, where her role was to establish the truth about the title character, in Man of Iron the function of the investigative journalist is taken by someone else, a man called Winkel. He is a radio journalist, sent to Gdańsk in the summer of 1980, during the time of the shipyard strike, which established Solidarity as the dominant political force for change in Eastern Europe. Winkel's task is to collect material which will discredit Maciek Tomczyk, one of the organisers of the strike. He meets various people to learn about Tomczyk's illegal activities. Agnieszka, who by then is Tomczyk's wife, is one of his interviewees.

Winkel meets Agnieszka in jail. She was imprisoned by the authorities to halt her involvement in the strike. Agnieszka tells Winkel, whom she remembers from the times she worked in television, what happened to her since she brought Tomczyk to Warsaw in 1976. Her story takes the form of flashbacks (which was also used in Man of Marble to present Birkut's history). We learn that she invited Tomczyk to visit the television studio in Warsaw, because at the time she was making her film, Birkut was already dead. He died in 1970, when tanks were used to crush workers' protests. As Tomczyk was the one, who told her about the fate of his father, Agnieszka hoped that including him in her film about the last years of Birkut will provide a powerful conclusion to her documentary. For the producer, however, making a film about the workers, standing against the socialist authorities was unacceptable, particularly in 1976, when the country 
was disturbed by a new wave of strikes in Ursus and Radom. He suggested that she shelve the project and when she fiercely resisted, he destroyed her television pass, informing her that she has no chance to work in the media. After this Agnieszka returned with Maciek Tomczyk to Gdańsk. The initial purpose was to finish her 'Falling Stars' documentary. Soon, however, she fell in love with Tomczyk and became involved in the anti-communist movement. The two events are presented as closely connected -- she fell in love with Tomczyk partly because she admired him for his involvement in the conspiracy against communist authority, and she engaged in the Solidarity movement, because she loved him.

Once Tomczyk enters Agnieszka's life, she changes her behaviour and values. In her conversation with Winkel Agnieszka admits that in Warsaw she was driven by ambition, she wanted success more than anything else. In Gdask, she loses this aspiration. More importantly, she discovers other values worth fighting for, such as improving the lives of the workers and replacing totalitarian rule with democracy. It is worth emphasizing that although Agnieszka embraced these values with an open heart, she did not discover them independently, but they were instilled in her by Maciek. Equally important was her discovery of the 'feminine' side of her personality, which surfaced in her desire to have a husband and a child. Their wedding is a powerful sign of her subordination to Maciek's way of life. She mentions to Winkel that she was never religious, but realised that they must have a church wedding, because all Maciek's friends (which means, everyone involved in Solidarity) were very religious and the Catholic Church itself was part of the pro-democracy movement. Moreover, the only guests who attend the ceremony are Solidarity activists, including the leader of the movement, Lech Wałęsa, played by Wałęsa himself, who is the groom's best man. In contrast, Agnieszka's family and friends, are absent, even her own father does not come.

The main impression one has from seeing Agnieszka in Gdańsk is one of extreme hardship, misery and claustrophobia. Her living conditions are very poor. First Agnieszka, who in Man of Marble was a creature of open space, moving freely between apartments and towns, shares a room with Maciek; the place is filled with old furniture, dark and grim, entrapping and suffocating. After Agnieszka and Maciek decide to organise an exhibition about the events of 1970, which resulted in the death of Mateusz Birkut and many of his fellow workers, the place is visited by various officials, representing the communist authorities, who try to dissuade the Tomczyks from their anti-state activities. Consequently, Maciek loses his job and is imprisoned. At the time Agnieszka who is heavily pregnant, finds work in a shop, moving heavy boxes in noisy rooms, pushed by people who seem to show no respect for her condition as an expectant mother. Separation from her family and living in Gdask, which in contrast to metropolitan Warsaw, feels very provincial, completes her claustrophobia.

Even when Maciek Tomczyk is in prison, he dominates Agnieszka's existence. At this stage she lives in the flat of old Mrs. Hulewicz, who was Maciek's close friend and widely known from her anti-communist views and activities. Maciek's colleagues from the shipyard visit Agnieszka, bringing her some money. Initially she refuses to take it, but eventually accepts, touched, but also humiliated by the ship workers generosity. This is a further testimony to her loss of independence and transformation into a woman who must be supported by men in order to survive. The final stage of Agnieszka's literal and metaphorical confinement is her imprisonment at the start of the shipyard strikes. At this time she can participate neither in ordinary life by working and earning her living, nor in the anti-government conspiracy. The fact that she is interviewed by Winkel not in reference to her own involvement in 'Solidarity', but to Maciek's, emphasizes her marginalisation and insignificance. In the story she gives Winkel, Agnieszka constantly undermines herself in relation to pre-Gdańsk times in order to present Maciek as wise and heroic. She uses expressions such: 'I was mad', 'I was stupid', 'I was a complete idiot'. In her opinion Maciek was the man who showed her what was important in life and changed her from an 'ambition freak' into a 'true woman'. At the same time, perhaps to avoid the accusation of constructing Maciek as an old-fashioned patriarch, Wajda makes Agnieszka say things which suggest that he is also a 'new man'. For example, she claims that at various stages of their life together, he encouraged her to return to her career as a filmmaker.

On the whole, the story which Agnieszka recounts to Winkel presents a metamorphosis of Wajda's heroine from being an independent woman into a 'Polish Mother. ${ }^{(8)}$ It is worth explaining that Polish Mother is an important national myth, originating in the $19^{\text {th }}$ century, in the time of Partitions, when Poland did not exist as a separate state. At that time men often left their families to fight for their country in the many uprisings and wars while the women remained at home to look after the whole household and to teach their young 
children their patriotic duties. It became accepted that without the strength and devotion of the Polish Mother Poland would not have survived as a cultural community. Polish Mother was almost synonymous with 'Polishness', as 'Poland' has very feminine connotations, such as the nurturing soil. There is also a strong affinity between Polish Mother and Holy Mother, the highest icon in the Catholic Church -- both selfless and defined not by their sexuality, but by their devotion to their sons. Furthermore, in common with the Holy Mother, who has power on Earth while her son has command in Heaven, Polish Mother executes authority over everyday life, while the men in her family apply their strength to more esoteric tasks. ${ }^{(9)}$

As Polish Mother, Agnieszka in Man of Iron is selfless and has no life of her own, but serves the men of her family: her son and husband. She is confined to her home, leaving politics and breadwinning largely to Maciek. However, I will also argue that in Man of Iron she does not even have the famous strength of the archetypal Polish Mothers, not mentioning her old determination. Her weakness is best shown in a scene, when the shipyard personnel officer visits Maciek to discourage him from organising a photographic exhibition in his flat. After the visit Agnieszka takes the pictures off the wall, burst into tears and must be comforted by Maciek.

The shift from a westernised, independent woman, who was Agnieszka in Man of Marble into Polish Mother in Man of Iron is signified visually, by changes in her costume and general appearance, as well as by camera positions and movements. Firstly, once Agnieszka started to share the flat with Maciek, her denim trousers and jacket are replaced by a denim dress. Afterwards we see her in a wedding dress and later in a wide, long, shapeless, maternity dress. While she became mother, she is never shown in trousers, but instead, in long dresses and coats. On one occasion we even see her with a scarf on her head of the kind old Russian women often wear. In prison she wears a narrow skirt, which, as Dorota Roszkowska suggests, symbolises her loss of freedom. ${ }^{(10)}$ Agnieszka's clothes in Man of Iron hide the attractiveness and sexual power, which she commanded in Man of Marble. The modest clothes emphasize her femininity, but in a maternal, not sexual sense. They also make her look much older than in the first part of Wajda's diptych. Although there is only five years between Wajda's shooting of Man of Marble and Man of Iron, the heroine's appearance suggests that many more years had passed. In her accelerated ageing she is also reminiscent of archetypal and real Polish Mothers.

Janina Falkowska draws attention to the fact that in the scene previously mentioned, when Maciek's comrades from the shipyard visit Agnieszka at home, she is stylised to look as Madonna and as a social realist monument. 'The construction of the mise en scene places Agnieszka, the madonna with unborn child who is looked up to by Birkut's fellow workers with pious adoration, in the centre of the picture. However, Agnieszka looks monumental, statuesque, presented without any ironical comment.(11) Falkowska also quotes Gilbert Adair, who notes that the way Agnieszka is photographed, bears associations with both Catholicism and social realism. 'In Man of Iron Agnieszka and Birkut's son was apotheosised -- statufied, so to speak -- as pious, forward-straining hero out of a tradition that can be described only as Stalinist. ${ }^{(12)}$ I agree with Falkowska that the origin of Agnieszka in Man of Iron is both Stalinist and Catholic. Paradoxically, the two ideologies have much in common in their approach to women, as on the surface they treat them with the highest respect, almost sanctify them. In reality, however, they offer women only secondary positions and thus marginalise them. The fact that pregnant Agnieszka is monumentalised suggests that the film's author approves of the transformation of his heroine from an independent and ambitious young woman into a prematurely aged Polish Mother. The story of Agnieszka can be compared to that of Norma Rae in the 1979 film by Martin Ritt -- in contrast to Norma Rae, who changes from a housewife into an independent woman and union activist, Agnieszka changes from an independent and politically active woman into a housewife. On the whole, Man of Iron is a very masculine film, where men initiate and take the main parts in the events portrayed, as well as carrying the film's ideological baggage. Women only support men, hidden in their shadows. This fate is not restricted to Agnieszka, but also includes the previously mentioned Mrs. Hulewicz, an old friend of Mateusz Birkut and Maciek Tomczyk. Characteristically, there are also no women of importance in the documentary footage, which Wajda included in his film. The Solidarity opposition, the communist authorities and the media are all represented by men, although the director shows that the masses of Solidarity members and supporters consisted largely of women.

Myths often express dominant ideologies. ${ }^{(13)}$ In the $19^{\text {th }}$ century the myth of the Polish Mother served the rule of patriarchy by expecting the woman to stand by her man (or the memory of him, if he died in battle) 
and by claiming that a woman's place at home determines her position in society. Consequently, I will argue, that the revival of the myth of Polish Mother in Wajda's film was accompanied by and conveyed the new attitudes to women, which took place about the time Man of Iron was made. I find strong analogies between the situation of Agnieszka and the attitudes to the roles of women in Polish society, as expressed by Solidarity, as well as the position of the real Solidarity heroines during and after the famous shipyard strikes in the 1980. As Ewa Hauser, Barbara Heyns and Jane Mansbridge note, 'in the 1980 Gdańsk Agreements, Solidarity created a number of special benefits for women, including generous leave for childbirth and child-rearing. These policies met women's real needs but also help maintain them in traditionally subordinate positions, reinforcing the image of woman as secondary wage earners focussed on family and home.(14) The view that a woman should devote herself primarily to home-making was supported by the increasingly anti-liberal and pro-Catholic attitude of Solidarity to abortion. As Hauser et al note, 'Solidarity's 1981 program did not call for the banning of abortion outright, but expressed a hope that with an improving economic situation the economic reasons for terminating pregnancy would be eased. After 1990, it became clear that the economic situation would not improve quickly. Consequently, the Solidarity position on abortion evolved to endorsing , in March 1990, a total ban on abortion, irrespective of economic or even health considerations.'(15)

Solidarity's position towards women, which can be described metaphorically as a desire to transform the ethos of the Polish Mother into a formal system of rights and duties, governed by the law, was accompanied by the marginalisation of women in the Solidarity movement and in the wider political and social life. As the previously quoted authors claim, 'Less than 8 percent of delegates to the first Solidarity Congress in 1981 were women, although female workers constituted almost one-half of the union membership.'(16) In the 1990s women constituted only a tiny minority in the leadership of Solidarity and in the AWS (Solidarity Election Action), a right wing political alliance, dominated by Solidarity politicians. Moreover, their stance in parliament was often identical to that of their male colleagues, or even more extreme in advocating women submitting to their traditional roles of mothers and homemakers. Some of the handful of women, who played prominent roles in the early Solidarity movement, such as Barbara Labuda, left Solidarity altogether in protest to its increasingly right wing and anti-liberal stance. Anna Walentynowicz, another prominent figure in the Solidarity movement a shipyard worker whose dismissal was the immediate cause of the strike in the 1980s (whose name is mentioned in Man of Iron), disappeared into complete obscurity.

It could be argued that in the 20 years since the shipyard strikes, the Solidarity movement has had no distinctive female politicians. As in Wajda's Man of Iron the women in Solidarity are mute, invisible and confined to their homes. The fact that Wajda and his scriptwriter, Aleksander Ścibor-Rylski created Agnieszka in Man of Iron as a Polish Mother is testimony to their political intuition, something for which Wajda was praised for most of his artistic career. However, Wajda's acceptance, even welcoming of Agnieszka's change into the Polish right wing's female role model is for me much less comforting. At the same time it confirms my conviction that the most famous Polish director is a political opportunist, hardly challenging his audience's deepest views or values.

\section{Agnieszka and Krystyna Janda}

In Europe, in contrast to America, we are accustomed to regard film characters as the sole creation of the director, at the expense of appreciating the input of scriptwriters, and even to a larger extent, of the actors. In many cases, however, the actors play such a significant part in shaping the role, given to them, that it is almost impossible to say if they 'play' or simply reveal their own character and personality. This is reflected in the attitude of the audience, who are unable to distinguish between the actor and their character, and endow the actor with the same feelings which they hold for the person they play. This is precisely the case of the actress who played Agnieszka -- Krystyna Janda. Janda was born in 1951 and Man of Marble was her film debut. Her role was regarded as a tremendous success and almost instantly Janda became a star of Polish cinema and idol of her generation. The audience attributed to the actress many of the characteristics of her heroine, simply perceiving her as Agnieszka.

In the light of Agnieszka's 'prior-history' and Janda's own experiences, the identification was to a large extent justified. The character of Agnieszka moved through a series of metamorphoses, before appearing on screen. In the first version of the script for Man of Marble, written by Aleksander Ścibor-Rylski in 1962, Agnieszka represented the generation of those born at the end of the 1930s and her role was relatively small and meaningless. She was described as looking no more than 20 years old, wearing a dark, tweed 
jacket, dark stockings and dark, high heels. Her clothes were rather old, but in good taste. The first Agnieszka was shy, lacking in self-confidence and silent. Ścibor-Rylski's script was eventually accepted by the political authorities in 1975. At this stage Agnieszka belonged to the generation of those born in the 1950s. However, her basic characteristics hardly changed; she was still meant to be shy and restrained. ${ }^{(17)}$ The final shape of Wajda's heroine was given by the actress, Wajda chose for the role. Janda says that when Wajda was looking for someone to play Agnieszka, he did not wish to employ a talented actress, someone with excellent acting technique, but a young woman with a strong personality. In one interview she quotes him as saying after her audition for the role in Man of Marble: 'She can kill, so she can play this role.(18) She had considerable freedom to shape Agnieszka, to instil her with her own opinions, mannerisms and idiosyncracies. Janda also claims that as a student in the theatre school she was interested in Polish 'idols', particularly Zbigniew Cybulski, the actor who played the main part in Wajda's Popiót $i$ diament (Ashes and Diamonds, 1958). ${ }^{(19)}$ She completely identified with Cybulski's opinion that 'to be an actor means to be able to smell his time, to be able to express the emotions of one's own generation. ${ }^{(20)}$ The young actress was fully aware of Agnieszka's uniqueness. She noticed that in contrast to the majority of the most memorable heroes of Polish cinema, particularly in films of the Polish School, who were doomed to failure, her heroine was determined and destined to win. Secondly, Agnieszka in Man of Marble did not suit the female stereotype in Polish cinema as subservient to men, unable to shape her own destiny. Janda was proud to play such an unusually strong woman. ${ }^{(21)}$ According to her own words, she also identified completely with the second incarnation of Agnieszka in Man of Iron and was even able to detect an affinity between Agnieszka's evolution and her own personal development. There is no resentment of her heroine being reduced to a secondary character. Janda commented: 'Man of Iron completed my education as a citizen. It confirmed my way of thinking about my country and its tragic history. Sometimes I think with horror that if I had not read certain books and meet certain people, I would remain a complete idiot. In the film there is a similar motif: thanks to Birkut, Agnieszka meets many wise people, who change her completely.... Revolutions are made by men, a woman must be his support, take care of their home. In this film I played a mature, wise Agnieszka and a national symbol. ${ }^{(22)}$

After her roles in Man of Marble and Man of Iron, amongst other films, Janda played in two later movies directed by Wajda, Bez znieczulenia (Rough Treatment, 1978) and Dyrygent (Conductor, 1979) and in a stream of films, in which she portrayed characters who rebel against communist authority, such as Stan wewnętrzny (Inner State, 1983), which will be discussed in due course and Przestuchanie (Interrogation, 1982) by Ryszard Bugajski. For the latter film she received many awards in Poland and abroad, including an award for best actress at the 1989 Cannes Festival. These roles confirmed Janda's status as a 'national actress', understood as someone whose motive for acting is less about earning money or gaining popularity, but rather to convey the aspirations and feelings of the whole nation. In the years that followed she tried to live up to this image both in the cinema and in her off-screen life. Apart from playing in many popular films both in Poland and abroad, she expressed her political views in numerous interviews, worked for children's charities, wrote articles for magazines and made a record. On the other hand, on the rare occasions when she revealed that she liked money and luxurious life, she was scorned by her admirers, as if they were unable to forgive Janda that she was not the selfless Agnieszka, but a star. In 1995 Janda made her debut as a film director, adapting for the screen Pestka (Stone) a bestseller written by Anka Kowalska in the 1960s about a tragic love affair between a married man and a single woman, played by Janda herself. Agata, Janda's character in the film, in spite of being at least ten years older than the heroine in Man of Iron, still reveals the same inner energy and intensity of feelings as Agnieszka. However, the energy is directed entirely to her private life -- Agata's love and suffering caused by her guilt for destroying her lover's family. There is no reference to politics in Janda's film; her character, although middle class and sophisticated (she works as a radio journalist and has a $\mathrm{PhD}$ degree) seems not to care about anything apart from her romance. Agata's total preoccupation with the private sphere might be regarded as symptomatic for the role, prescribed for women by the respective postcommunist governments, as well as to Janda's own change of interests.

In the last decade Janda was still regarded as the greatest female star of post-war Polish cinema and a role model for a new generations of young Polish actresses. Yet, her status as a 'political actress' or 'national symbol' significantly weakened after the collapse of communism. Her most memorable roles in the last fifteen years or so have been in theatre plays, which she has frequently directed. Amongst other roles, she played Maria Callas and Marlene Dietrich. Janda herself is sceptical about her future in Polish cinema. In an 
interview, given in March 2000, she said: '[Polish] cinema is now made by the young generation. They have their own subjects, their own actors, their own problems. As for me, I can possibly play the mother of a thief or a gangster'.(23) In another interview Janda admits that while she was a symbol of the 1970s, the 1990s belong to Katarzyna Figura, an actress of immense sex appeal, regarded as a Polish Marilyn Monroe, who specialised in contemporary comedies. 'She is really needed now by the directors to tell their stories'(24), says Janda of Figura. At the same time, one can detect a note of disappointment in many of the interviews the actress gave in recent years and her yearning to repeat her early successes. Janda seems to believe that her chance to play someone in the same league as Agnieszka depends on Wajda's willingness to employ her again. In an interview she noted: 'I do not know Andrzej Wajda's intentions, but whatever they are, I will be happy to respond to them. ${ }^{(25)}$ Interestingly, after Agnieszka, Wajda was unable to create any interesting and memorable female characters, in spite of the fact that women were cast in the principal roles in two of his later films, Wielki tydzień (Holy Week, 1995) and Panna Nikt (Miss Nobody, 1996).

\section{Other Solidarity Heroines}

The impact of Man of Marble and Man of Iron in the history of Polish cinema was so great, that they initiated a wider phenomenon of films, depicting the history of Solidarity and putting a female heroine at the centre of the narrative. Two films, in particular, are of particular interest to me, Stan wewnętrzny (Inner State, 1983) by Krzysztof Tchórzewski and Człowiek z... (Man of..., 1993) by Konrad Szolajski, as in a sense they provide new versions or continuations of the stories of Wajda's characters.

Ewa, the main character in Inner State is played by Krystyna Janda. This encourages a comparison between the heroines of Wajda and Tchórzewski's films. Ewa is a sailor and Solidarity activist, who in 1981 embarks from Gdańsk on a single-handed round the world yacht race, with the ambition of breaking the world record. When martial law was introduced in December 1981, many of her friends, including those working in the Gdańsk shipyard, who helped her to realise her sailing ambitions, lose their jobs or are interned by the communist government. Ewa encounters a moral dilemma: to finish her race, as the military authorities want her to do and to return home as an 'official hero', or to remain in exile somewhere in the West, or to return to Poland without finishing the race. In spite of having very limited information about the situation in Poland, she chooses the last option and returns to Poland, risking persecution by the military authorities.

If we assume that Ewa is an 'older Agnieszka in disguise', Inner State confirms the image of Agnieszka as somebody who remained faithful to the ideals of solidarity and resistance against communism. In this respect, Ewa is similar to both Agnieszkas in Man of Marble and Man of Iron. Her ambition to achieve something unusual and 'masculine' (there are very few yachts women, who embark on long, single-handed races), as well as her unusual energy and mobility, surpassing both men and women around her, place her closer to the first incarnation of Wajda's heroine. Moreover, although she fails to complete the race, she breaks the world sailing record. On the other hand, in common with Agnieszka in Man of Iron, Ewa relies heavily on men, in this case on her ex-husband, her boss and lover, thanks to whom her yacht is of world class quality, and her friend, who works in television. There is also some uncertainty about her main motive in interrupting the race, as she returns to Poland knowing that she is pregnant by her ex-husband. Ewa's future remains open. We do not learn if she will suspend her career as a professional sailor and devote herself to motherhood completely, or if she will try to reconcile the various aspects of her life. On the whole, the author of Inner State tries somehow to reconcile Agnieszka in Man of Marble with Agnieszka in Man of Iron, imbuing her with features of Wajda's heroine from the two stages of her life. Sadly, the film fails to enrich the portrayal of the Solidarity heroine, created by Wajda; it feels as if Ewa is comprised entirely of various clichés, Wajda used in the two films.

Another film which reworks the story, presented in Man of Marble and Man of Iron, albeit in a very different way, is Człowiek z... (Man of..., 1993) by Konrad Szolajski. Szolajski's film, being one of the handful of successful comedies of the 1990s, is a caricature of Wajda's epics. Its heroine, Anna, a young film school graduate is mistaken by the military police for an anti-communist conspirator during the martial law of 1982. She emigrates to the West and returns in 1989 as a celebrity to a democratic Poland. Her former boss suggests that she make a film about the activist of the anti-communist opposition, Marek Mirkut. In common with Agnieszka, who tried to discover the past of Mateusz Birkut by watching films and newsreels, made in the 1950s, Anna spends long hours in the archives of the office of national security, watching documentary footage, showing Mirkut's work in the Solidarity underground. Most importantly, she learns 
that he joined Solidarity not so much to fight against the communist oppressors, as to win the heart of a girl, called Maria, who suffered 'neurosa eroica', being unable to fall in love with anybody except a hero. Marek's story consists of many events typical for Solidarity figures, which were included in Wajda's films and recycled by Tchórzewski and some other directors, who made films about the 1980s. For example, Marek organised the escape of a member of the opposition. He was also interned during martial law and eventually won the heart of Maria. However, none of the events in Szolajski's film looks as they did when immortalised in the 'Solidarity myth'. The general impression is that martial law was not particularly harsh, and that many people joined the anti-communist opposition for reasons which were less than noble, and after the collapse of communism cynically used it as a passport to a career in politics and business.

In Man of... two women bear certain similarities with Agnieszka: Anna resembles Agnieszka in Man of Marble and Maria resembles the heroine of Man of Iron. However, the similarity between Anna and Agnieszka is rather superficial, referring only to their roles in the narrative structures, not to their personalities. Phlegmatic and lacking in initiative, good-natured, even slightly naive, Anna is less than a shadow of her cinematic predecessor. Moreover, her career in cinema and politics is a result of a series of lucky coincidences, not her own work and determination, as it was in the case of Agnieszka. Her warm prettiness and feminine clothing further emphasize the gap between Wajda's and Szolajski's heroines. We can find more meaningful similarities between Agnieszka and Maria. Maria, as Wajda's heroine, yearns to do something important and patriotic. Moreover, in tune with the tradition of Polish Mother, to which Agnieszka in Man of Iron conformed, Maria gives up the role of an independent agent and takes the role of supporter of the man, whom she loves. She encourages him to take part in the most dangerous and heroic acts of anti-communist conspiracy and supports him during martial law, by visiting him in a camp for interned conspirators, disguised as a man. Unfortunately, she tries so hard not to be recognised by the camp guards, that she virtually changes into a man. Consequently, Marek, who can not give up his love for Maria (who became Marian), changes his gender too, becoming a woman, called Maria. The sex change of the main characters might be treated simply as farcical, adding to the postmodern style of the film by creating associations with such classics as Some Like It Hot (1959) by Billy Wilder or the Polish popular comedy Poszukiwany, Poszukiwana (Searching For, 1972) by Stanislaw Bareja. The director himself, in an interview which I conducted in 1999, played down the importance of gender issues in his film, claiming that it was simply a comedy device. However, it can also be read in the context of the 'gender politics' of Wajda's films, as Szolajski's criticism or even mockery of Wajda's decision to highlight the men and marginalise the women in Man of Iron. Szolajski does this by portraying Maria as being much braver and more determined than the men, engaged in the Solidarity conspiracy, the men being weak and effeminate. Man of... might also be regarded as a re-writing or deconstruction of the Polish Mother myth. By showing Maria as fulfilling her Polish Mother's duties of patriotism with extreme seriousness and determination, Szolajski demonstrates that she not only outshines her man, but changes him into a passive tool of her own plans, and thus makes him unimportant.

In common with Ewa, Anna and Maria do not function as real women, but only as re-presentations, or variations of Wajda's heroine, and they are not meaningful alternatives to Wajda's Agnieszka. This can be regarded as much a testimony to the talent of Andrzej Wajda and Krystyna Janda to create a convincing and memorable character, as to the inability of Polish filmmakers to portray Polish women as co-creators of the Solidarity movement, or even as politically active. Tchórzewski, Szolajski and some others, such as Feliks Falk, the director of Koniec gry (The End of the Game, 1991) about a female politician-kleptomaniac, who must choose between love and career, try to give women more prominent parts, but fail to make them convincing. It is worth adding that in the films made in the second half of the 1990s and the beginning of the next decade, women are typically either literally absent from the films, or marginalised in the narratives. In the few films, where they have more prominent parts, they are portrayed as enemies of male protagonists, presented in an unfavourable light and usually punished in the narratives. Tato (Dad, 1995), directed by Maciej Slesicki can serve as an example. In this film virtually all the women are bad and intellectually inferior to men, but one of the most negative representations is of a member of a 'Parliamentary Women's Circle' as a dogmatic, insensitive militant feminist. The portrayal emulates the popular perception of the circle's leader and ex-Solidarity activist, Barbara Labuda. The main cause of this new attitude to women in Polish cinema, in my opinion, is the surge in patriarchalism and misogyny, which has permeated official Polish culture since the collapse of communism. Thus, to put it metaphorically, Agnieszka had some less talented sisters, but no daughters, and her beloved son grew to be a more patriarchal man than his father. 


\section{Notes}

1. Maria Kornatowska, Wodzireje i amatorzy (Warszawa: Wydawnictwa Artystyczne i Filmowe: 1990), 98.

2. See Andrzej Walicki, Philosophy and Romantic Nationalism. A Case For Poland (Clarendon Press, 1982).

3. Laura Mulvey, 'Visual Pleasure and Narrative Cinema' in Antony Easthope (ed), Contemporary Film Theory, (London: Longman, 1993), 111-124.

4. Tadeusz Sobolewski, 'Cierpiacy posag', Kino, (8/1989), 22.

5. Ibid., 15, Piotr Lis, 'Człowiek z marmuru' in Jan Trzynadlowski (ed) Problemy teorii dziela filmowego (Wroclaw: Wydawnictwo Uniwersytetu Wrocławskiego, 1985), 88.

6. Maciej Koziol, 'Dominujace wizerunki kobiet w filmie polskim po 1945 roku', Studia Filmoznawcze XII, (1992), 240, Maria Kornatowska, Eros i film (Lódź: Krajowa Agencja Wydawnicza, 1986), 178-179, Wiktor Woroszylski, 'Człowiek z kielnia, człowiek z kamera', Wiez, 56 (1977), 187.

7. Dorota Roszkowska, 'Człowiek z drugiej strony. Kobiety w filmach Wajdy' in Sławomira Walczewska (ed), Glos maja kobiety (Kraków: Convivium, 1992), 79-80.

8. The Polish Mother qualities of Agnieszka in Man of Iron were noted by several critics. See Dorota Roszkowska, op. cit., Janina Falkowska, The Political Films of Andrzej Wajda (Providence: Berghahn Books: 1996) and Elzbieta Ostrowska, 'Filmic Representations of the 'Polish Mother' in Post-Second World War Polish Cinema', The European Journal of Women's Studies 5, 1998.

9. See Elzbieta Ostrowska, 'Filmic Representations of the 'Polish Mother' in Post-Second World War Polish Cinema', The European Journal of Women's Studies 5, 1998.

10. Dorota Roszkowska, op. cit., 80-81.

11. Janina Falkowska, op. cit., 146.

12. Ibid., 146.

13. See Roland Barthes, Mythologies (New York: Hill and Wang, 1972).

14. Ewa Hauser, Barbara Heyns and Jane Mansbridge, 'Feminism in the Interstices of Politics and Culture: Poland in Transition' in Nanette Funk and Magda Mueller (ed) Gender Politics and Post-Communism (New York, London: Routledge, 1993), 262.

15. Ibid., 262. 16. Ibid., 262. 17. Dorota Roszkowska, op. cit., 79.

18. Zbigniew Metzel, 'Sto procent siebie', Polityka, (25/1978), 16.

19. Ibid., 16. 20. Dorota Roszkowska, op. cit., 79. 21. Zbigniew Metzel, op. cit., 16-17.

22. Bozena Janicka, Krystyna Janda, Gwiazdy maja czerwone pazury (Warszawa: Wydawnictwo W.A.B, 1999), 58.

23. Ewa Galazka, 'Trzeba o mnie specjalnie pomyslec', Gazeta Telewizyjna, (17-23/03/2000, 4.

24. Jestem glupkiem domowym', Elle (1/1998)), 22.

25. Ewa Galazka, op. cit., 4.

\section{Author Information}

Ewa MAZIERSKA is Professor of Contemporary Cinema at the Department of Humanities, University of Central Lancashire. Her publications include Masculinity in Polish, Czech and Slovak Cinema, Roman Polanski: The Cinema of a Cultural Traveller, Women in Polish Books (with Elżbieta Ostrowska), Crossing New Europe: The European Road Movie (with Laura Rascaroli), Dreams and Diaries: The Cinema of Nanni 
Moretti, and From Moscow to Madrid: Postmodern Cities, European Cinema. She also co-edited Relocating Britishness. 